УДК 378.04:7.012]:001.8

DOI:

Лариса Гриценко, кандидат педагогічних наук, доцент кафедри теорії і методики технологічної освіти

Полтавського національного педагогічного університету імені В.Г. Короленка

Георгій Негай, кандидат архітектури, доцент кафедри архітектури і містобудування Хмельницького національного університету Людмила Страшко, кандидат архітектури, доиент кафедри архітектури і містобудування Хмельницького національного університету

\title{
РЕАЛІЗАЦІЯ МЕТОДОЛОГІЧНОГО ПРИНЦИПУ СИСТЕМНОСТІ НАВЧАННЯ У ПРОЦЕСІ ГРАФІЧНОЇ ПІДГОТОВКИ ФАХІВЦІВ ТЕХНОЛОГІЙ І ДИЗАЙНУ
}

Стаття присвячена дослідженню потенціалу методологічного принципу системності навчання у процесі інженерно-графічної підготовки фахівців технологій і дизайну. Здійснено аналіз проблеми реалізаціі системного підходу у графічній підготовці студентів в історичній ретроспективі. Запропоновано $i$ апробовано творчі завдання з креслення і дизайну з елементами проєктної діяльності (втілення принципу системності навчання): формування графічних умінь, розвиток просторового мислення, формування графічноі культури.

Ключові слова: модернізація вищої освіти; методологічний принцип; системність навчання; графічні уміння студентів; просторове мислення; графічна культура.

Jim. 16.

Larysa Hrytsenko, Ph.D.(Pedagogy), Associate Professor of the Theory and Methods of Technology Education Department,

Poltava V. G. Korolenko National Pedagogical University

Georgiy Negay, Ph.D.(Architecture), Associate Professor of the Architecture and Urban Planning Department, Khmelnytsk National University

Liudmyla Strashko, Ph.D.(Architecture), Associate Professor of the Architecture and Urban Planning Department, Khmelnytsk National University

\section{REALIZATION OF METHODOLOGICAL PRINCIPLE OF SYSTEMATIC TEACHING OF SPECIALISTS IN TECHNOLOGY AND DESIGN}

The article is devoted to the study of theoretical and methodological principles and conceptual aspects of teaching engineering and graphic disciplines to students of engineering, technical and pedagogical specialties in the context of higher education modernization. The potential of the methodological principle of systematic teaching of specialists in technology and design in the process of their engineering and graphic training is analyzed. The analysis of the systematic approach realization in the process of students' graphic training in historical retrospect is carried out. The types of systematic approach in research on student training are covered. A retrospective of the application of the principle of systematic teaching in the professional study of graphic disciplines in higher education is revealed. It is proved that the implementation of modern information technologies in the process of higher education is impossible without using the potential of the methodological principle of systematic teaching.

A review of scientific sources on the problem of engineering and graphic training of specialists in technology and design is done. It is proved that the integrity of the formation of graphic skills of a specialist in technology and design with the developed spatial thinking and a high level of graphic culture can be achieved due to the implementation of the methodological principle of systematization in the learning process. The research of methodological potential of the principle of systematic teaching is carried out.

Keywords: modernization of higher education; methodological principle; systematic training; students' graphic skills; spatial thinking; graphic culture.

П остановка проблеми. Реформування освітньої галузі $є$ процесом періодичним і відбувається у кожній розвиненій країні світу. Інтенсивно модернізується і графічна підготовка майбутніх фахівців (“закони України "Про вищу освіту”, "Про наукову і науково-технічну діяльність”, “Галузеві стандарти вищої освіти”,
2020 р.). При цьому “...графічні дисципліни (технічне креслення, нарисна геометрія, інженерна графіка) включені у навчальні плани підготовки студентів біля 70 спеціальностей вищих закладів освіти I-IV рівнів акредитації, але у старшій школі вивчення креслення передбачено тільки у класах технологічного профілю. В академічних групах 
серед студентів першого курсу, в яких вивчається нарисна геометрія, зустрічаються досить часто випадки, коли біля 50 \% студентів не мають початкових графічних знань та вмінь" $[1,3]$. Згідно 3 робочими програмами графічних дисциплін, процес формування графічних умінь студентів вищої школи передбачає набуття ними теоретичних та практичних знань 3 виконання технічних зображень для використання у процесі проєктування; умінь виконувати макети, креслення, розгортки, перспективи і аксонометрії фрагментів; готовності розробляти креслення для прийняття функціональних архітектурнохудожніх, об'ємно-планувальних та конструкторських рішень; здатності виконувати розрахунковографічні завдання; спроможності документально та презентабельно відображати творчий задум. При цьому наявність розвиненої просторової уяви, є обов'язковою [13]. Цілісність формування графічних умінь фахівця технологій i дизайну при розвиненому просторовому мисленні та високому рівні графічної культури може бути досягнута, на наш погляд, внаслідок здійснення принципу системності у процесі навчання. Дослідження потенціалу дидактичного принципу системності навчання під час набуття комплексної готовності до професійної діяльності майбутнього фахівця $є$ метою пропонованої статті.

Виклад основного матеріалу. У фокусі дослідження постає актуальність розгляду ретроспективи застосування принципу системності навчання у професійному вивченні графічних дисциплін у вищій школі. Розвиток графічних умінь, просторового мислення та формування високого рівня графічної культури в єдиній системі потребує використання алгоритму системи дидактичних завдань.

Протягом тривалого історичного періоду дидактичні дослідження грунтуються на методології системного підходу до аналізу явищ та їх удосконалення, адже “методологія педагогіки $\epsilon$ системою знань про структуру педагогічної теорії, про принципи підходу і способи набуття знань, які відображають педагогічну дійсність, а також системою діяльності з одержання таких знань і обгрунтування програм, логіки, методів і оцінки якості дослідницької роботи”; “особливість методологічних принципів полягає у визначенні вихідних наукових позицій, які є загальними для всіх галузей, і одночасно теорією наукового пізнання у конкретній галузі науки" [5, 498].

Основним методом дослідження є діалектичний, що дає змогу обгрунтувати причиново-наслідкові зв'язки, постійну суперечність між сутністю і явищем, змістом і формою, об'єктивність в оцінюванні дійсності [16, 169]. Крім того допомагає дослідити явище по-перше, у розвитку; по-друге, у взаємозв'язках; по-третє, у зв'язках 3 іншими явищами, що і $є$ системністю. "Втілені у ньому принципи дослідження цілісного (сходження від абстрактного до конкретного; єдності аналізу та синтезу; логічного й історичного; виявлення в об'єкті різноякісних зв'язків та їх взаємодії; синтезу структурнофункціональних уявлень про об'єкт тощо) є найважливішими компонентами діалектичної методології наукового пізнання" [7, 124].

Принцип методології - це основоположне начало, пізнавальна установка дослідника чи наукової школи (суб'єкта, який пізнає), що визначає можливість використання того чи того прийому, способу, засобу, методу чи методики для наукового пізнання об'єкта (предмета) дослідження. Але іноді відбувається порушення розуміння ієрархічного зв'язку методу і принципу.

“Якщо основи науки стоять на верхній сходинці ієрархії логічної структури науки, то закони - на нижчій. Закони, по суті, виконують функції фактичної бази науки: відображають предмет даної науки і носять всезагальний характер. Як факти закони носять достовірний характер: у процесі розвитку науки вони не спростовуються, змінюється тільки сфера їхнього застосування, тому закони науки - об'єктивно істинні. Закони становлять кістяк теоретичних побудов, а відкриття закону - одне із головних завдань будь-якого наукового дослідження. Функції законів виступають принципами істинного знання, що є в даній науці. Поняття “закон” і “принцип” у науці одноступеневі й важко розрізняються. Закон стає принципом науки, коли виконує логічну функцію в систематизації знання, служить вихідним положенням у побудові теорій в дослідженні нового знання” [16, 13].

Однак, “як правило, у вітчизняній науці при визначенні поняття “методологія”, - зауважує А. Машков, - не робиться акцент на методологічні принципи як основу формування методології. Більше того, доволі часто при розгляді питань, які стосуються методології методологічні принципи зовсім не згадуються" [8].

Дослідженню теоретичних засад системного підходу у вищій освіті присвятили свої роботи Л. Березівська, Л. Даниленко, В. Докучаєва, Г. Сльнікова, Є. Хриков, Г. Цехмістрова та інші $[5,499]$. Автори підручників 3 педагогіки визначають принципи навчання як “основні положення, які у відповідності до загальних цілей 


\section{РЕАЛЗЗАЦІЯ МЕТОДОЛОГІЧНОГОПРИНЦИПУ СИСТЕМНОСТІ НАВЧАННЯ}

У ПРОЦЕСІ ГРАФІЧНОӤ ПІДГОТОВКИ ФАХІВЦІВ ТЕХНОЛОГІЙ І ДИЗАЙНУ

та закономірностей навчального процесу визначають зміст, організаційні форми та методи навчання” (І. Підласий); “як визначену систему вихідних, основних дидактичних вимог, установок до процесу навчання, виконання яких забезпечує ефективність практичної діяльності” (В. Лозова). Актуальним є дослідження А. Харківської, присвячене обгрунтуванню необхідності системного підходу під час упровадження інновацій в освітній процес вищої школи $[15,350]$.

Аналіз спеціальної літератури з досліджуваної проблеми дає підставу Р. Дружененко констатувати відсутність єдиного визначення поняття “педагогічна система", що зумовлене диференціацією загальнонаукового системного підходу на підвиди. Зокрема, В. Беспалько у визначенні поєднує системно-структурний та системно-функційний підходи і розуміє педагогічну систему як “сукупність взаємопов’язаних засобів, методів і процесів, необхідних для створення організованого, цілеспрямованого і передбачуваного педагогічного впливу на формування особистості". На засадах системно-історичного підходу до вивчення системних педагогічних явищ вибудовують наукову концепцію О. Любар, М. Стельмахович, Д. Федоренко. Серед типів системного підходу дослідники називають системно-цільовий, системно-компонентний, системно-структурний, системно-функційний, системно-діяльнісний, системно-миследіяльнісний, системно-історичний $[4,20]$.

Поділяючи означену позицію, констатуємо, що наявне велике розмаїтість типів системного підходу та структурних компонентів систем і їх значущості заважає досліджувати істинну сутність явища, розмиває його базові зв'язки: компонентами (елементами) педагогічної системи є мета, зміст, принципи, методи, прийоми, засоби, форми, результати навчально-виховної діяльності; основна функція педагогічної системи - управління педагогічною діяльністю.

У античній філософії термін “система" характеризував упорядкованість і цілісність природних об'єктів. Наука епохи Відродження виробилапевну концептуальну базу, найважливішими категоріями якої є предмет і властивість, ціле і частина, форма та зміст. Г. Гегель запропонував історичне трактування системи відповідно до принципу сходження від абстрактного до конкретного. Надалі фіксується наявність особливих інтегративних характеристик цієї сукупності, тобто цілісність, не зведення до простої суми складових елементів. Сама ия сукупність, відношення між елементами (їхн координація, субординація тощо) визначаються певним правилом або системоутворювальним принциипом. Функції системи реалізуються через зв'язки, тобто через потоки енергії, людей, матеріальні й інформаційні.

Системний підхід у науковому дослідженні передбачає наявність класифікації зв'язків, зокрема: взаємодії (координації), серед яких можна розрізнити: зв'язки властивостей; зв'язки об'єктів; зв'язки породження (генетичні); зв'язки перетворення; зв'язки побудови (структурні); зв'язки функціонування; зв'язки розвитку; зв'язки управління [7, 29-30].

Отже, основним елементом у структурі теорії, який визначає іiї зміст, є приниип. Він утворює верхній рівень теорії. На цьому рівні функціонують й основні поняття, судження і закони. Вони незалежні, не зумовлені одне одним. Фундаментальними категоріями системного підходу є: одиничне, особливе, загальне; причина і наслідок; необхідність і випадковість; можливість і дійсність; зміст і форма; сутність і явище; частина і ціле; структура і елементи [8].

Відтак зважаючи на викладене, констатуємо, що “графічна підготовка вчителя технологій $€$ цілісним системним утворенням, основними складовими якої виступають геометро-графічна (вміння виконувати геометричні побудови, робота зі схемами, рисунками, діаграмами та ін.), художньо-графічна (графічний дизайн, створення графічних композицій, колажів, орнаментів та ін.) та інженерно-графічна підготовка (виконання графічної конструкторської документації, читання технічних схем, креслеників, реалізація завдань проєктної діяльності та ін.)" [16, 6].

Проблема інженерно-графічної підготовки молоді доволі широко досліджувалася багатьма вітчизняними та зарубіжними науковцями. Так, теоретичні основи графічної підготовки школярів і студентів знайшли відображення у підручниках i навчальних посібниках $€$. Антоновича, С. Боголюбова, Д. Борисова, В. Ваніна, В. Вяткіна, В. Левицького, В. Михайленка, А. Хаскіна та ін.; методичні засади навчання графічних дисциплін учителя технологій (трудового навчання, креслення) висвітлені О. Ботвінніковим, А. Верхолою, І. Вишнепольським, В. Гервером, I. Голіяд, С. Дембінським, Д. Кільдеровим, В. Кузьменком, І. Ройтманом, В. Сидоренком та ін.

Теоретико-методологічні засади та концептуальні аспекти навчання графічних дисциплін студентів інженерно-технічних і педагогічних спеціальностей досліджувалися у дисертаціях А. Бойко, А. Гедзика, О. Джеджули, М. Козяра, І. Нищака, Г. Райковської, В. Сидоренка, М. Юсупової та ін.

Можливості реалізації завдань графічної 
підготовки молоді засобами інформаційних технологій досліджувалися О. Глазуновою, Н. Голівер, Р. Горбатюком, В. Кондратовою, М. Ожгою, Ю. Фещуком та ін.

Аналіз науково-педагогічної літератури, дисертаційних робіт, дав підставу зробити висновок, що, незважаючи на розмаїття напрямів дослідження, науковцями приділено недостатньо уваги проблемі підвищення рівня інженернографічної підготовки вчителя технологій; відсутні єдині підходи щодо створення та реалізації цілісної методичної системи навчання інженернографічних дисциплін у педагогічних 3ВО [11].

Сутність інженерно-графічної підготовки розкрито в Концепції технологічної освіти : "Технологічна освіта-процес і результат засвоєння системи знань про сучасне виробництво, формування комплексу вмінь поводження із засобами праці, підготовка підростаючого покоління до активної предметно-перетворювальної діяльності" [6, 3-11].

Досить детально розглянуті в дослідженнях Г. Райковської теоретико-методичні засади графічної підготовки майбутніх фахівців технологічних спеціальностей; обгрунтовано інноваційну концепцію модернізації графічної підготовки у вищому технічному закладі [12].

Дослідницею О. Джеджула обгрунтовано теоретичну модель графічної діяльності, яка включає: науковообгрунтовану структуру графічної діяльності, механізми послідовності переробки графічної інформації, етапи розгортання психологічних процесів під час оперування графічною інформацією та відтворює повний розгорнутий цикл графічної діяльності [3].

Неможнапроминупиувагоюдослідження І.Нищака, присвячене обгрунтуванню концептуальних засад системи навчання інженерно-графічних дисциплін у ЗВО та шляхів її реалізації. На його думку, уміння - це здатність індивіда максимально продуктивно, якісно і в установлений час здійснювати діяльність у нових умовах. При цьому систему практичних дій він вбачає у відборі необхідних знань, виділенні суттєвих властивостей, практичному перетворенні (застосуванні) знань, контролі і коригування результатів діяльності та ін. Натомість інженернографічними навичками I. Нищак уважає вдосконалені вміння інженерно-графічної діяльності, що реалізуються на рівні несвідомого контролю та забезпечують досягнення найкращого результату з найменшим розумовим напруженням $[11,58]$. М. Вачевський називає їх “особистісними і міжособистісними якостями, здібностями, навиками і знаннями, які виражені в різних формах і багатообразних ситуаціях роботи і соціального життя" [1].
За А. Гедзиком, “графічна підготовка - це багатогранний та взаємообумовлений процес, спрямований на сприйняття, усвідомлення, систематизацію та подання графічної інформації, а також формування й розвиток властивостей $\mathrm{i}$ якостей особистості, необхідних у майбутній професійній діяльності” $[2,14]$.

Отже, сучасні дослідження проблеми вироблення інженерно-графічних умінь гідно продовжують класичну наукову спадщину, вносять інноваційні елементи, збагачують іiі. Водночас відбувається деяке неупорядковане нагромадження підходів, втрачання цілісності самого явища. Наприклад, питання змісту підготовки відділяються від учасників процесу; питання прийомів навчання бувають відірваними від психолого-педагогічних основ їх застосування.

Опрацьовуючи алгоритм втілення принципу системності у процесі графічної підготовки фахівців технологій та дизайну, ми аналізували механізми вироблення графічних умінь та типи завдань, які сприяють формуванню не тільки умінь та навичок, але й розвивають просторове мислення студентів, впливають на підвищення рівня їх графічної культури.

I. Нищак розподіляє інженерно-графічні задачі на групи:

- пропедевтичні (навчальні) - формування цілісної системи знань, умінь, розвиток мислительних процесів, формування основ графічної культури;

- задачі виробничого спрямування виготовлення об'єктів праці;

- творчі і графічні задачі, спрямовані на самостійну науково-пошукову діяльність: конструювання, реконструювання, переконструювання технічних об'єктів і систем $[11,35]$.

“При проєктуванні студент повинен уміти застосовувати сучасні засоби і методи інженерної графіки, будувати ортогональні проекції геометричних тіл і архітектурних форм, зрізи та розгортки поверхонь, наочні зображення на основі аксонометрії і лінійної перспективи, власні та падаючі тіні предметів за різних умов освітлення; уявляти форму предметів за їх проєкційним зображенням, виконувати i оформляти архітектурно-будівельні креслення та іншу проєктну документацію відповідно вимог державних стандартів і нормативів; повинен володіти правилами побудови геометричних об'єктів в різних типах проєкційно-зображальних систем, методикою розв'язування позиційних та метричних задач, способами побудови аксонометричних і перспективних проєкцій; засобами підвищення наочності зображень 


\section{РЕАЛІЗАЦІЯ МЕТОДОЛОГІЧНОГОПРИНЦИПУ СИСТЕМНОСТІ НАВЧАННЯ}

У ПРОЦЕСІ ГРАФІЧНОӤ ПДГОТОВКИ ФАХІВЦІВ ТЕХНОЛОГІЙ І ДИЗАЙНУ

світлотіньовим моделюванням для розробки архітектурних проєктів нового будівництва i проєктів реконструкції та реставрації існуючих об'єктів" [13].

I. Нищак (за В. Симоненком і М. Ретивих) визначає комплекс професійно-практичних умінь фахівця технологій та дизайну:

1) графічні або інженерно-графічні - уміння читати і розробляти креслення, схеми, виконувати розрахунково-графічні роботи та ін.;

2) конструктивні - уміння розробляти технологічні процеси та конструювати технічні пристрої, розробляти навчальну і технікотехнологічну документацію, виконувати конструкторські роботи, складати технологічні карти та ін.;

3) технологічні - уміння аналізувати виробничі ситуації, планувати, раціонально організовувати технологічний процес, експлуатувати технологічні пристрої, користуватися різальними та контрольно-вимірювальними інструментами та iн.;

4) виробничо-операційні - загальнотрудові вміння з суміжних професій;

5) спеціальні - вузькопрофесійні вміння у межах певної галузі виробництва $[11,59]$.

Нами виділено чотири групи умінь: 1) аналітичні формуються упроцесі аналізуі синтезу просторових ознак і відносин графічних об'єктів; 2) узагальнювальні-в процесі читання графічної інформації; 3) конкретизуючі - в процесі створення графічних зображень; 4) конструктивні - в процесі перетворення графічної інформації. На наше переконання, усі завдання, які пропонуються студентам, мають бути згруповані за видами умінь, які вони можуть формувати. Таким чином, студент буде бачити, яке завдання йому слід обрати для заповнення власних прогалин у процесі навчання. Але для створення цілісного процесу підготовки фахівця цього недостатньо.

Важливою складовою означеного процесу $\epsilon$ формування просторового мислення студентів. Сутність просторової уяви полягає у тому, що свідомість, використовуючи безпосередньо дані просторові образи, перетворює їх у нові, створює нову просторову ситуацію. Процес формування просторових уявлень характеризується певною етапністю: створення цілісного образу на наочній основі або абстрактно-логічній основі шляхом спирання на раніше засвоєне поняття; оперування образом в односкладних зв'язках у дещо змінених умовах, закріплення його істотних ознак шляхом варіювання неістотних ознак; оперування образом в дуже змінених умовах внутрішньопредметних $і$ міжпредметних взаємозв'язків і взаємозалежностей; творче конструювання нових образів і відношень на основі раніше узагальнених, рухливих і дійових образів. На кожному етапі повинна застосовуватися специфічна система методів формування і розвитку просторових уявлень [10].

Аналіз науково-методичної літератури показав, що необхідною умовою формування просторового мислення є наявність сформованості його показників. До них відносять: успішність створення просторового образу, адекватного графічного зображення; типи оперування образами, широта оперування, повнота образу. Ми також вважаємо, що успішність у процесі формування просторового мислення може бути досягнута, якщо матиме місце спільна усвідомлена діяльність вчителя і учня, в процесі якої має здійснюватися посилене формування особистості студента за рахунок таких принципів iii функціонування: активності, діалогічності, самостійності, ініціативності, творчості, розгляду учня як відкритої, здатної до саморегулювання (вибору освітньої траєкторії) і самоорганізації системи [10]. Поєднуючи завдання на формування просторового мислення із завданнями за формування різних груп умінь та вироблення графічної культури, ми досягаємо створення цілісної картини формування фахівця як у предметному так і в особистісному розумінні.

Підгрунтям формування творчої особистості, вважає Д. Тхоржевський, є графічні знання: "Графічні знання і вміння - це один із факторів, що сприяють загальнокультурному розвитку людини, ії готовності до неперервної освіти та професійної діяльності” [14, 47-51].

На думку О. Коберника, “Проєктне навчання передбачає системне й послідовне моделювання тренувального розв'язання проблемних ситуацій, що вимагають від учасників освітнього процесу пошукових зусиль, спрямованих на дослідження та розроблення оптимальних шляхів їх розв'язання (проєктів), їх неодмінний публічний захист та аналіз підсумків упровадження". Специфічні навички проєктування: - проблематизація, цілепокладання та планування діяльності, самоаналіз та рефлексія, презентація діяльності та результатів, вміння готувати та використовувати продукт проєктування, пошук потрібної інформації, практичне застосування знань; вибір, освоєння і використання адекватної технології створення продукту проєктування, проведення дослідження (аналіз, синтез, висування гіпотези, деталізація та узагальнення) [6, 717-718].

3-поміж вимог до створення системи завдань, що активізують візуальне мислення студентів, 


\section{РЕАЛІЗАЦІЯ МЕТОДОЛОГЧЧНОГОПРИНЦИПУ СИСТЕМНОСТІ НАВЧАННЯ}

У ПРОЦЕСІ ГРАФІЧНОӤ ПІДГОТОВКИ ФАХІВЦІВ ТЕХНОЛОГІЙ І ДИЗАЙНУ

виділяємо такі: широке використання уяви фігури подумки, використання зображення фігур; цілеспрямоване формування візуальних аналогів математичних понять, тобто створення банку візуальних образів, які допомагають розпізнавати ті чи ті факти, поняття, способи діяльності; розмежовування аналітичних методів розв'язування задач і візуальних методів; формування візуальних образів на неоднорідній наочній основі, тобто варіювання ознак; використання геометричних об'єктів різної складності, які вимагають добудови, перебудови, перетворення для отримання відомого геометричного об'єкта; використання задач на відокремлення певних візуальних образів із заданої графічної інтерпретації - формування вибіркової візуальної уваги студента [9].

Уважаємо за корисне вчити студентів використовувати різні знаково-символічні засоби для інтерпретування даних та вимог задачі, переходити від одного виду інтерпретації до іншого. Особливо це стосується задач, в яких постає необхідність оперування просторовими об'єктами. Наприклад, під час вивчення взаємного розміщення прямих, прямої та площини доцільно розкривати зміст задачі - тексту за допомогою реальних предметів (олівців, аркушів тощо). Як результат - студент сам знаходить зв'язок між заданими об'єктами задачі, що допомагає йому її розв'язати, а головне закріпити теоретичний матеріал 3 теми. Надалі, із виробленням навичок визначення взаємного розміщення прямих у просторі, прямої та площини, студент може не звертатися до реальних предметів, макетів і навіть до їх матеріалізованих замінників - рисунків. Збагачений візуальнооперативний досвід студентів допомагатиме опанувати потрібні дії в уяві. Візуальні задачі можна розділити на два типи: задачі за готовими рисунками; задачі, умови, яких формулюються 3 опорою на реальні предмети, макети.

"Практика навчання на перших курсах вузу такої дисципліни як інженерна графіка постійно виявляє слабкий розвиток теоретичного, так i практичного характеру, у зв'язку з відсутністю просторового мислення студентів. Вони часто не справляються із завданнями як специфічного виду розумової діяльності, а саме просторового мислення. У своїх найбільш розвинених формах це є мислення образами, в яких фіксуються просторові властивості і відносини” [16, 102].

На переконання А. Гедзика, “креслення - це фундамент графічної культури людини, яка живе в сучасному технологічному світі” [2].

Погоджується 3 такою думкою I. Нищак:
“... інженерно-графічну культуру вчителя технологій доцільно розглядати як інтегральну характеристику професійно-особистісних якостей педагога, що відображає високий рівень знань, умінь і навичок та практичного досвіду, необхідних для успішного розв' язання інженерно-графічних задач професійного та навчального спрямування; здатність до рефлексії власної інженернографічної діяльності, самовдосконалення й підвищення фахового рівня" [11, 45].

Алгоритм реалізації принципу системності навчання включає три комплекти завдань на формування: 1) графічних умінь, 2) просторового мислення, 3) графічної культури фахівців. Таким чином, реалізується єдиний підхід до опрацювання матеріалу 3 урахуванням індивідуальних особливостей студентів, здійснюється цілісний процес підготовки особистості фахівця, втілюється методологічний принцип системності навчання.

Аналіз графічної діяльності, що відбувається під час конструювання, архітектурного чи дизайнерського проєктування, уможливив виявити основні напрями в розробці творчих задач.

Центральне місце серед них займають задачі, що пов'язані з технічним конструюванням, яке дає можливість використовувати приклади 3 багатьох важливих напрямів науково-технічної діяльності. Дослідження різних видів робіт, рекомендованих при навчанні конструювання, показало, що найбільш зрозумілими, близькими логіці побудови креслень для студентів є:

- відтворення відсутньої ланки конструкції (конструювання);

- конструювання відповідно до технічних умов (з використанням графічної основи).

Вказані види навчальної роботи активізують навчальний процес, оскільки найбільш тісно пов'язані з використанням графічних зображень. Слід відзначити і відносну простоту таких завдань порівняно із конструюванням за схемою чи за описом.

Враховуючи зміст навчальної діяльності, пропонується використовувати задачі 3 елементами не тільки конструювання, а й проєктування в області архітектури і дизайну.

До творчих завдань 3 креслення 3 елементами проєктної діяльності пропонується включити розробку і виконання:

1. Креслення фасаду простої одноповерхової будівлі за їі планом.

2. Креслення плану будинку за його зображенням у перспективі або в аксонометрії.

3. Креслення плану будівлі за його фасадом.

4. Креслення архітектурних композицій 
(фронтальних, об’ємних) з використанням простих геометричних тіл.

5. Ескізів елементів форми заданого об'єкту (з предметно-графічними опорами).

До творчих завдань 3 дизайну з елементами проєктної діяльності пропонується включити:

1. Доопрацювання елементів форми (зовнішніх) заданого об’єкту (з предметно-графічними опорами).

2. Створення ескізу зовнішньої форми групи предметів за стилістичними ознаками одного 3 них.

3. Удосконалення естетичних якостей об'єкта на основі аналізу конструкції.

4. Художнє конструювання простих об’єктів за їх технічними характеристиками.

Висновки. Згідно з метою статті, здійснено ретроспективний аналіз реалізації методологічного принципу системності навчання у процесі підготовки фахівців технологій і дизайну.

Розроблений та перевірений алгоритм виконання завдань для формування системи графічних умінь дає змогу реалізувати принцип системності навчання у процесі підготовки фахівця технологій і дизайну: виконання завдань на формування графічних умінь, розвиток просторового мислення, формування графічної культури.

\section{ЛІТЕРАТУРА}

1. Вачевський М. Сутність компетенцій у навчальному процесі та компетентнісний підхід у професійній освіті. Молодь і ринок. 2012. № 8. C. 25-32.

2. Гедзик А. М. Дидактичні основи структури та змісту креслення в загальноосвітній школі : автореферат дис. на здобуття ступеня канд. пед. наук : спец. 13.00.02. “Теорія та методика навчання креслення” . Київ, 2006. 18 с.

3. Джеджула О. М. Теорія і методика графічної підготовки студентів інженерних спеціальностей вищих навчальних закладів : дисертація на здобуття наук. ступеня докт. пед. наук: спец.: 13.00.04. Київ, 2007. 460 с.

4. Дружененко Р. С. Роль педагогічного системного підходу в оформленні поняття “методична система навчання мови". Наукові записки Бердянського державного педагогічного університету. Серія : Педагогічні науки. Вип. 1. Бердянськ : БДПУ. 2018. 284 с.

5. Енциклопедія освіти / Акад. пед. наук України; головний ред. В. Г. Кремень. Київ : Юрінком Інтер, 2008. 1040 c.

6. Коберник О. М., Сидоренко В. К. Концепція технологічної освіти учнів загальноосвітніх закладів України. Трудова підготовка в закладах освіти. 2010. № 6. С.3-11.

7. Кустовська О. В. Методологія системного підходу та наукових досліджень : курс лекцій. Тернопіль : Економічна думка, 2005. 124 с.

8. Машков А. Проблеми теорії держави і права. Основи : курс лекцій. Київ : К. І. С., 2008. 470 с.

9. Моторіна В. Г. Технології підготовки вчителя математики до уроку : навчальний посібник для студентів фізико-математичннх факультетів педагогічних навчальних закладів; друге доповнене і виправлене видання. Харків : Видавництво Іванченка I. С., 2012. 318 с.

10. Моторіна В. Г. Розвиток просторової уяви майбутніх вчителів математики в процесі їх геометричної підготовки. Проблеми математичноі освіти (ПМО - 2015) : матеріали міжнар. наук.метод. конф., м. Черкаси, 4-5 черв. 2015 р. Черкас. нац. ун-т імені Б. Хмельницького. Черкаси : ЧНУ, 2015. С. 164-166.

11. Нищак I. Д. Методична система навчання інженерно-графічних дисциплін майбутніх учителів технологій: дисертація на здобуття наук. ступеня докт. пед. наук : спец. 13.00.02 - “Теорія та методика навчання креслення". Дрогобич. $2016.425 \mathrm{c}$

12. Райковська Г. О. Наукові підходи та сучасний стан з графічної підготовки майбутніх фахівців у ВНЗ. Вісник Житомирського державного університету ім. І. Франка. 2007. № 35. С. 109-114.

13. Силабус. Навчальна дисципліна "Нарисна геометрія і будівельне креслення". Освітньопрофесійна програма “Архітектура та містобудування”. Рівень вищої освіти перший бакалаврський. Хмельницький національний університет. 2020.9 с.

14. Тхоржевський Д. О. Державний стандарт загальної середньої освіти і диференціація змісту навчання. Педагогіка і психологія. 1999. № 4. C. $47-51$.

15. Харківська А. А. Теоретичні та методичні засади управління інноваційним розвитком педагогічного ВНЗ: монографія. Харків : ХГПА, $2011.350 \mathrm{c}$.

16. Чернілевський Д. В. Методологія наукової діяльності: навч. посібн.: Вид. 2-ге, допов. / За ред. проф. Д. В. Чернілевського. Вінниця : Видво АМСКП, 2010. 484 с.

\section{REFERENCES}

1. Vachevskyi, M. (2012). Sutnist kompetentsii u navchalnomu protsesi ta kompetentnisnyi pidkhid $\mathrm{u}$ profesiinii osviti [Competence in the educational process and competence approach in vocational 
education]. Youth \& market. No. 8. pp. 25-32. [in Ukrainian].

2. Hedzyk, A. M. (2006). Dydaktychni osnovy struktury ta zmistu kreslennia $\mathrm{v}$ zahalnoosvitnii shkoli [Didactic bases of structure and the maintenance of the drawing in comprehensive school]. Candidate's thesis. Kyiv, 18 p. [in Ukrainian].

3. Dzhedzhula, O. M. (2007). Teoriia i metodyka hrafichnoi pidhotovky studentiv inzhenernykh spetsialnostei vyshchykh navchalnykh [Theory and methods of graphic training of engineering students of higher educational institutions]. Doctor's thesis. Kyiv, 460 p. [in Ukrainian].

4. Druzhenenko, R. S. (2018). Rol pedahohichnoho systemnoho pidkhodu v oformlenni poniattia "metodychna systema navchannia movy" [The role of the pedagogical system approach in the design of the concept "methodical system of language learning"]. Scientific notes of Berdyansk State Pedagogical University. Series: Pedagogical sciences. Vol. 1. Berdiansk, 284 p. [in Ukrainian].

5. Entsyklopediia osvity (2008). [Encyclopedia of Education]. Academy of Pedagogical Sciences of Ukraine; (Ed.).V. H. Kremen. Kyiv, 1040 p. [in Ukrainian].

6. Kobernyk, O. M. \& Sydorenko, V. K. (2010). Kontseptsiia tekhnolohichnoi osvity uchniv zahalnoosvitnikh zakladiv Ukrainy [The concept of technological education of students of secondary schools of Ukraine]. Labor training in educational institutions. No. 6. pp.3-11. [in Ukrainian].

7. Kustovska, O. V. (2005). Metodolohiia systemnoho pidkhodu ta naukovykh doslidzhen : kurs lektsii [Methodology of systems approach and research: Course of lectures]. Ternopil, 124 p. [in Ukrainian].

8. Mashkov, A. (2008). Problemy teorii derzhavy i prava. Osnovy : kurs lektsii [Problems of the theory of state and law. Basics: Course of lectures]. Kyiv, 470 p. [in Ukrainian].

9. Motorina, V. H. (2012). Tekhnolohii pidhotovky vchytelia matematyky do uroku [Technologies for preparing a mathematics teacher for a lesson]. $A$ textbook for students of physics and mathematics faculties of pedagogical educational institutions, the second supplemented and corrected edition. Kharkiv, 318 p. [in Ukrainian].

10. Motorina, V. H. (2015). Rozvytok prostorovoi uiavy maibutnikh vchyteliv matematyky v protsesi yikh heometrychnoi pidhotovky [Development of spatial imagination of future mathematics teachers in the process of their geometric training]. Problemy matematychnoi osvity (PMO - 2015) : materialy mizhnar. nauk.-metod. konf., m. Cherkasy, 4-5 cherv. $2015 r$. - The problems of mathematical education (PMO - 2015). Proceedings of the international. Scientific Method Conf., Cherkasy, June 4-5. 2015 (pp. 164-166). Cherkasy. [in Ukrainian].

11. Nyshchak, I. D. (2016). Metodychna systema navchannia inzhenerno-hrafichnykh dystsyplin maibutnikh uchyteliv tekhnolohii [Methodical system of teaching engineering and graphic disciplines of future teachers of technology]. Doctor's thesis. Drohobych, 425 p. [in Ukrainian].

12. Raikovska, H. O. (2007). Naukovi pidkhody ta suchasnyi stan z hrafichnoi pidhotovky maibutnikh fakhivtsiv u VNZ [Scientific approaches and current state of graphic training of future specialists in universities]. Bulletin of Ivan Franko Zhytomyr State University. No. 35. pp. 109-114. [in Ukrainian].

13. Sylabus. (2020). Navchalna dystsyplina "Narysna heometriia i budivelne kreslennia". Osvitnoprofesiina prohrama "Arkhitektura ta mistobuduvannia". Riven vyshchoi osvity pershyi bakalavrskyi [Course "Descriptive Geometry and Construction Drawing". Educational and professional program "Architecture and Urban Planning”. The level of higher education is the first bachelor's degree]. Khmelnytsky National University. 9 p. [in Ukrainian].

14. Tkhorzhevskyi, D. O. (1999). Derzhavnyi standart zahalnoi serednoi osvity i dyferentsiatsiia zmistu navchannia [State standard of general secondary education and differentiation of educational content]. Pedagogy and psychology. No.4. pp. 4751. [in Ukrainian].

15. Kharkivska, A. A. (2011). Teoretychni ta metodychni zasady upravlinnia innovatsiinym rozvytkom pedahohichnoho VNZ: monohrafiia [Theoretical and methodical bases of management of innovative development of pedagogical high school: monograph]. Kharkiv, 350 p. [in Ukrainian].

16. Chernilevskyi, D. V. (2010). Metodolohiia naukovoi diialnosti: navch. posibn. [Methodology of scientific activity: textbook. manual]. Vol. 2nd, add. (Ed.).D. V. Chernishevsky. Vinnytsia, 484 p. [in Ukrainian].

Стаття надійшла до редакції 17.12.2020

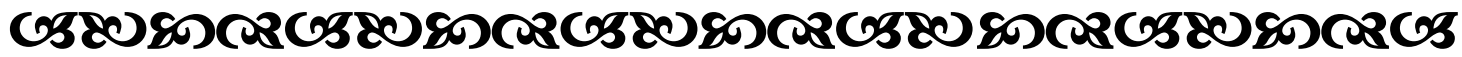

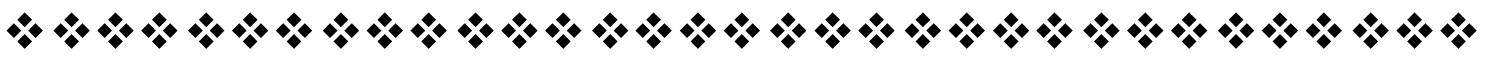

